\title{
Physico-chemical and Functional Properties of Fresh Eel (Mastacembelus armatus) Muscle Proteins
}

\author{
Rohini Mugale*, S.B. Patange, V.R. Joshi, G.N. Kulkarni and M.M. Shirdhankar \\ Department of Fish Processing Technology and Microbiology \\ College of Fisheries, Shirgaon, Ratnagiri - 415629 Maharashtra, India \\ *Corresponding author
}

\section{A B S T R A C T}

In the present study, physico-chemical and functional properties such as solubility, $\mathrm{Ca}^{2+}$ ATPase activity, total sulfhydryl group, emulsion activity index, emulsion stability, foam volume stability (FVS), foam volume capacity, gelation, water holding capacity (WHC) of muscle proteins from fresh eel (Mastacembelus armatus) fish were studied.

\section{Keywords}

Fresh eel fish,

Functional properties

\section{Article Info}

Accepted:

20 February 2018

Available Online:

10 March 2018
Solubility value of sarcoplasmic (SPP) and myofibrillar protein (MFP) was 44.93 and $59.16 \mathrm{mg} / \mathrm{g}$ respectively. It is higher in MFP than SPP fraction. $\mathrm{Ca}^{2+} \mathrm{ATPase}$ activity of actomyosin was $0.50 \mu$ mole $\mathrm{Pi} / \mathrm{mg}$ protein/min, total sulfhydryl group of MFP fraction was $48.27 \mu$ mole $\mathrm{SH} / \mathrm{g}$ protein. The emulsion activity index and emulsion stability was higher in MFP than SPP fraction at 2.5 and $5.0 \mathrm{mg} / \mathrm{ml}$ concentration. The values for viscosity of MFP and SPP were more at concentration of $5.0 \mathrm{mg} / \mathrm{ml}$ than $2.5 \mathrm{mg} / \mathrm{ml}$. The viscosity was more in MFP fraction than SPP fraction. Foam expansion and foam volume stability of MFP and SPP fraction at concentration of $2.5 \mathrm{mg} / \mathrm{ml}$ was lesser than $5 \mathrm{mg} / \mathrm{ml}$. The gel forming ability of fresh eel protein was $250 \mathrm{~g} . \mathrm{cm}$ and water holding capacity of eel mince was $2.53 \mathrm{~g} / \mathrm{g}$ muscle. The present study conclude that eel muscle protein have good functional properties. Functional properties of muscle proteins revealed that the eel fish can be one of the promising candidate species for utilization in preparation of functional foods like emulsion-type and/or sausage products.

\section{Introduction}

The freshwater spiny eel (Mastacembelus armatus) has great economic value especially in inland areas of India (Talwar and Jhingran, 1991). Among the commercially exploited fresh water fishery resources Indian major carps, minor carps, Chinese carps and eels constitute an important commercial fishery in riverine and reservoir fisheries. Eels represent an important commercially exploited fish in the local fish markets in the inland areas. Proteins are endowed with a number of physico-chemical and functional characteristics, which make them suitable for varied food applications such as thickeners, emulsifiers etc. Functional properties of proteins play a significant role in food applications and are very much influenced by their structure in food systems (Ramachandran et al., 2007). The molecular basis of functionality is related to their 
structure and ability to interact with other food ingredients (Zayas, 1997). Actin and myosin constitute the basic functional component of the myofibrillar proteins (MFPs). There are reports that fish undergo dramatic changes in the fiber type composition (myosin expression and organization of fiber type) and in the isoforms of myofibrillar molecule during post hatching growth (Watabe and Ikeda, 2006). Understanding physico-chemical characteristics is of utmost importance as it is directly related to the final quality of products like surimi, sausage and battered products. The functional properties of meat depend mainly on myofibrillar proteins (Goll et al., 1977) and are related to the composition and structure of proteins and their interaction with other substances present in the food (Colmenero and Borderias, 1983). The functional properties of myofibrillar proteins are important in determining the quality of the product (Roura and Crupkin, 1995). Functional properties of various fresh water fish protein were studied viz. tilapia (Parthiban et al., 2005, 2015), rohu (Mohan et al., 2006).

\section{Materials and Methods}

Fresh eel (Mastacembelus armatus) harvested from Krishna river in Sangli district and brought in ice condition to Ratnagiri fish landing center were purchased. The fish had total length of 30 to $55 \mathrm{~cm}$ and weight ranged between $225 \pm 13.22 \mathrm{~g}$.

Fishes were de-skinned and filleted. The fillets were minced in a kitchen mixer/grinder and boneless meat was used under a temperature of $2-4^{\circ} \mathrm{C}$ throughout the experiment. Extraction of muscle protein fraction was estimated according to the method of King and Poulter (1985). Protein determination of MFP and SPP extracts were estimated according to Gornall et al., (1948) by Biuret method. Extraction of natural actomyosin was prepared according to the method described by Benjakul et al., (1997). The ATPase assay of actomyosin was estimated according to the method of MacDonald and Lanier (1994). Inorganic phosphates were estimated by the method of Fiske and Subbarow (1925). The total SH groups of myofibrillar protein fraction were estimated according to Sedlak and Lindsay (1968). The ability of the proteins, SPP and MFP to form emulsion was estimated as emulsion activity index (EAI) according to the method of Pearce and Kinsella (1978) and as per modification of Cameron et al., (1991). About $20 \mathrm{ml}$ sample was prepared for estimation of viscosity of salt soluble and water-soluble protein at different concentrations $(2.5$ and $5.0 \mathrm{mg} / \mathrm{ml})$. It was determined with a (Model DV II + Pro, Brookfield) viscometer at shear rate $100 \mathrm{rpm}$ as described by Mohan et al., (2006). Foam ability of the protein was determined by the method of Wild and Clark, (1996).The waterwashed fish mince was used to get the concentrate of MFP. Heat-induced gels were prepared from MFP concentrate by grinding with $3 \%$ Sodium chloride for $2 \mathrm{~min}$ at $4^{\circ} \mathrm{C}$ (Lan et al., 1995). Water holding capacity (WHC) of mince was carried out by the method of Kocher and Foegeding (1993) with slight modification.

\section{Results and Discussion}

\section{Solubility of proteins}

The functional properties of proteins are often affected by protein solubility and those most affected are thickening, foam expansion, emulsifying and gel strength. As an indication whether or not denaturation has taken place in myofibrillar protein, a method commonly used is to measure the quantity of myofibrillar protein extracted from the muscle by salt solution with 0.45-0.6 ionic strength (Suzuki, 
1981). Extractability is related to the solubility of the protein and characteristics of the muscle structure. The solubility characteristics of proteins are related to the amino acid composition at protein surface and its interaction with the solvent (Bigelow, 1967). In the present study, solubility of sarcoplasmic and myofibrillar fractions of fresh eel were observed to be 44.93 and 59.16 $\mathrm{mg} / \mathrm{g}$ respectively.

Partiban et al., (2005) observed the 66\% solubility of MFP and 34\% of SPP of total soluble protein of fresh tilapia fish, Mohan et $a l$. , (2006) reported the solubilities of SPP and MFP of rohu fish were 47.6 and $76.5 \mathrm{mg} / \mathrm{g}$ respectively. Ramachandran et al., (2009) observed the solubilities of SPP of $O$. mossambicus, $M$. cephalus, $H$. molitrix and $C$. carpio were $32.15,53.29,46.65$ and 66.67 $\mathrm{mg} / \mathrm{g}$ tissue respectively whereas, the MFP solubilities of $O$. mossambicus, M. cephalus, $H$. molitrix and C. carpio were 152.34, 116.85, 80.91 and $152.54 \mathrm{mg} / \mathrm{g}$ tissue respectively. Parthiban et al., (2015) observed the solubilities of SPP and MFP of tilapia fish were 21.26 and $35.23 \mathrm{~g} / 100 \mathrm{~g}$ respectively.

\section{$\mathrm{Ca}^{2+}$ ATPase activity of actomyosin of eel}

The myosin globular has ATPase activity (which releases the energy for muscle contraction) and binds to actin in the absence of ATP (post-mortem). Therefore, $\mathrm{Ca}^{2+}$ ATPase activity can be used as an indicator of the integrity of myosin molecules (Benjakul et al., 1997) as the globular heads of myosin are responsible for $\mathrm{Ca}^{2+}$ ATPase activity (Benjakul et al., 2003; Ramachandran et al., 2007). In the present study, the $\mathrm{Ca}^{2+}$ ATPase activity of actomyosin of fresh eel was $0.50 \mu$ mole $\mathrm{Pi} / \mathrm{mg}$ protein $/ \mathrm{min}$. Ramachandran et al., (2009) reported the $\mathrm{Ca}^{2+}$ ATPase activity of MFP of $O$. mossambicus, M. cephalus, $H$. molitrix and C. carpio were $0.41,0.59,0.41$ and 0.28 respectively. The $\mathrm{Ca}^{2+}$ ATPase activity of actomyosin fraction was $0.81 \mu$ mole $\mathrm{Pi} / \mathrm{mg}$ protein/min in the fresh tilapia (Parthiban et al., 2015).

\section{Total sulfhydryl content of MFP of eel}

Sulfhydryl groups are considered to be the most reactive functional groups in proteins and any destruction of cysteine or cystine during storage of fish is indicated by disappearance of $\mathrm{SH}$ groups. The $\mathrm{SH}$ groups represent the reactivity of the proteins and the content of surface reactive $\mathrm{SH}$ groups increases with the unfolding of protein during exposure to extreme conditions (Sankar and Ramachandran, 2005). In the present study, the content of total sulfhydryl groups of MFP fraction of fresh eel was $48.27 \mu$ mole $\mathrm{SH} / \mathrm{g}$ protein. The Mohan et al., (2006) reported SH groups content of $88 \mu \mathrm{moles} / \mathrm{min} / \mathrm{mg}$ in AM from fresh rohu fish. Ramachandran et al., (2009) the concentration of reactive sulphydryl groups ranged from $23.5 \mu$ moles $\mathrm{SH} / \mathrm{g}$ protein to $44.7 \mu$ moles $\mathrm{SH} / \mathrm{g}$ protein among fishes and the highest values were recorded in MFP from silver carp and the lowest in common carp. Parthiban et al., (2015) observed the total SH content of actomyosin of fresh tilapia fish was $23 \mu \mathrm{moles} / \mathrm{min} / \mathrm{mg}$ AM.

Emulsion activity index (EAI) and Emulsion stability (ES) of SPP and MFP of eel

The emulsifying properties of proteins are evaluated by several methods, such as size distribution of oil droplets formed, emulsifying activity, emulsion capacity and emulsion stability (Kinsella and Melachouris, 1976). The physical and sensory properties of protein- stabilized emulsion depend on the size of the droplets formed and the total interfacial area created. The ability of proteins to bind fat in comminuted meat is of great importance. Proteins being amphoteric molecules, are surface-active agents and thus concentrate on fat-water interface. Emulsion 
stability refers to the ability of a protein to form an emulsion that remains unchanged for a particular duration, under specific conditions. Protein-stabilized emulsions are often stable for days.

In the present study, the EAI of MFP and SPP of eel at concentration of $2.5 \mathrm{mg} / \mathrm{ml}$ were 2.8 and $2.5 \mathrm{~m}^{2} / \mathrm{g}$ respectively. Whereas, the EAI of MFP and SPP of fresh eel recorded at concentration of $5.0 \mathrm{mg} / \mathrm{ml}$ were 3.1 and 2.2 $\mathrm{m}^{2} / \mathrm{g}$ respectively. Partiban et al., (2005) observed the EAI value was $124 \mathrm{~m}^{2} / \mathrm{g}$ for extracted total soluble protein from fresh tilapia fish. Mohan et al., (2006) reported the EAI of SPP at concentration of $2.5 \mathrm{mg} / \mathrm{ml}$ was $11.86 \mathrm{~m}^{2} / \mathrm{g}$ whereas, the EAI content of MFP at concentration of 2.5 and $5.0 \mathrm{mg} / \mathrm{ml}$ were 1.09 and $6.25 \mathrm{~m}^{2} / \mathrm{g}$ respectively. Ramachandran et al., (2009) observed the EAI of MFP values of fresh water fishes $O$. mossambicus, $M$. cephalus, $H$. molitrix and $C$. carpio with different habitat were $2.86,5.22$, 7.24 and $3.10 \mathrm{~m}^{2} / \mathrm{g}$ respectively.

In the present study, the ES of MFP and SPP of fresh eel at concentration of $2.5 \mathrm{mg} / \mathrm{ml}$ were 55 and 38 min respectively. The ES of MFP and SPP at concentration of $5.0 \mathrm{mg} / \mathrm{ml}$ was 60 and 40 min respectively. Partiban et al., (2005) observed the ES value was $570 \mathrm{sec}$ of fresh tilapia sample. Mohan et al., (2006) reported the ES values for SPP at concentration of $2.5 \mathrm{mg} / \mathrm{ml}$ was $52 \mathrm{~min}$ whereas, the ES content of MFP at concentration of 2.5 and $5.0 \mathrm{mg} / \mathrm{ml}$ were 87 and $364 \mathrm{~min}$ respectively. Ramachandran et al., (2009) recorded the ES of $O$. mossambicus, $M$. cephalus, $H$. molitrix and $C$. carpio were $53.33,86.67,53.33$ and 72.60 min respectively.

\section{Viscosity of SPP and MFP of eel proteins}

The consumer acceptability of several liquid and semisolid type foods (e.g., gravies, soups, beverages, etc.) depends on the viscosity or consistency of the product. Viscosity is a functional property which is greatly exploited when proteins are added to liquid foods as thickeners, and it affects several other functional properties. Myosin present in muscle proteins is the major contributor to the viscosity of aqueous muscle extracts.

In the present study, the viscosity of eel MFP at concentration of 2.5 and $5.0 \mathrm{mg} / \mathrm{ml}$ was 2.3 and $2.5 \mathrm{cP}$ respectively whereas, the viscosity of eel SPP at concentration of 2.5 and 5.0 $\mathrm{mg} / \mathrm{ml}$ was 1.9 and $2.3 \mathrm{cP}$ respectively. Partiban et al., (2005) reported the viscosity of tilapia fish protein was $3.25 \mathrm{~mm} / \mathrm{sec}$. Mohan et al., (2006) observed the viscosity of rohu SPP at concentration of $2.5 \mathrm{mg} / \mathrm{ml}$ was $1.36 \mathrm{cP}$ and for eel MFP at concentration of 2.5 and $5.0 \mathrm{mg} / \mathrm{ml}$ was 4.45 and $16.20 \mathrm{cP}$ respectively. Ramachandran et al., (2009) recorded the viscosity of MFP of fresh water fish viz. O. mossambicus, $M$. cephalus, $H$. molitrix and $C$. carpio from different habitat. The values of viscosity was lowest in the MFP of C.carpio (3.29 cP) and highest in $H$. molitrix $(13.39 \mathrm{cP})$.

Foam expansion (FE) and foam volume stability (FVS) of SPP and MFP of eel proteins

Foams consist of an aqueous continuous phase and a gaseous (air) dispersed phase. The unique textural properties and mouthfeel of these products stem from the dispersed tiny air bubbles. In most of these products, proteins are the main surface active agents that help in the formation and stabilization of the dispersed gas (foam) phase.

In the present study, the foam expansion of MFP of eel at concentration of 2.5 and 5.0 $\mathrm{mg} / \mathrm{ml}$ were 3.1 and $3.0 \%$ respectively. The foam expansion of SPP of eel at concentration of 2.5 and $5.0 \mathrm{mg} / \mathrm{ml}$ were 2.4 and $2.3 \%$ respectively. Foam stability refers to the ability of proteins to stabilize foam against 
gravitational and mechanical stresses whereas, the foam volume stability of MFP of eel at concentration of 2.5 and $5.0 \mathrm{mg} / \mathrm{ml}$ were 60.5 and $65.3 \%$ whereas, the FVS of SPP of eel at concentration of 2.5 and 5.0 $\mathrm{mg} / \mathrm{ml}$ were 28.8 and $35.6 \%$ respectively. Mohan et al., (2006) observed the FE of SPP of rohu at concentration of $2.5 \mathrm{mg} / \mathrm{ml}$ was $41.33 \%$ and the FE of MFP of rohu at concentration of 2.5 and $5.0 \mathrm{mg} / \mathrm{ml}$ were 105.33 and $134.66 \%$. The FVS of SPP of rohu at concentration of $2.5 \mathrm{mg} / \mathrm{ml}$ was $27.33 \%$ whereas, the FVS of MFP of rohu at concentration of 2.5 and $5.0 \mathrm{mg} / \mathrm{ml}$ were 89.00 and $87.00 \%$ respectively. Ramachandran et al., (2009) reported the FVS of fresh water fishes viz. O. mossambicus, $M$. cephalus, $H$. molitrix and $C$. carpio were 60 , 70,60 and $50 \%$ respectively; whereas, the FE of these fishes were 100, 70,180 and 55\% respectively. $H$. molitrix had better foam expansion it did not show much foam stability.

\section{Gel strength of muscle proteins of MFP of eel fish}

Gel is made up of polymers cross-linked via either covalent or non -covalent bonds to form network i.e capable of entrapping water and other small molecular weight substances. The strength of the gel depends on the extent of cross links that occur in the polypeptide chain. Proteins from fish differ in their ability to cross link to form network and found to be highly species specific (Mehta et al., 2011).

In the present study, the gel strength of fresh eel was 250 g.cm. The similar study done by other researcher, Partiban et al., (2005) recorded the gel strength of fresh tilapia fish was 710 g.cm. Ramachandran et al., (2009) also reported the gel strength of fresh water fish viz. O. mossambicus, $M$. cephalus, $H$. molitrix and $C$. carpio harvested from different habitat were 281.09, 282.72, 180.19 and 166.16 g.cm respectively.

\section{Water holding capacity of muscle proteins of eel fish (WHC)}

In food applications, the WHC of the protein is more important than water binding capacity (WBC). It refers to the sum of bound water, hydrodynamic water and physically entrapped water. The physically entrapped water contributes more to the water holding capacity. Many functional properties of proteins depend on water-protein interaction as water molecules bind to several groups in proteins. Myofibrils are the largest waterholding filament lattices and most of the water in the meat is held within the myofibrils in the narrow channels between the filaments (Sankar, 2009). In the present study, the water holding capacity (WHC) of fresh eel mince was $2.53 \mathrm{~g} / \mathrm{g}$ muscle. Similar study was done by Partiban et al., (2005) observed the WHC of fresh tilapia was $2.8 \mathrm{~g} / \mathrm{g}$ muscle.

\section{References}

Benjakul, S., Seymour, T. A., Morrissey, M. T. and An, H. (1997) Physico-chemical changes in Pacific whiting muscle proteins during iced storage. J. Food Sci., 62: 729-733.

Benjakul, S., Visessanguan, W., Thongkaew, C and Tanaka, M. (2003) Comparative study on physicochemical changes of muscle proteins from some tropical fish during frozen storage. Food Res Intl. 36: 787-95.

Bigelow, C. C. (1967) On the average hydrophobicity of proteins and the relation between and protein structure. J. Theoretical Biol., 16: 187.

Cameron, D. R., Weber, M. E., Idziak, E. S. Neufeld, R. J. and Cooper, D. G. (1991) Determination of interfacial areas in emulsions using turbid metric and droplet size data: Correction of the formula for emulsifying activity index. J. Agric. Food Chem., 39: 655-659. 
Colmenero, J. and Borderias, A.J. (1983) A study of the effect of frozen storage of certain functional properties of meal and fish protein. J. Food Technol., 18: 731737.

Fiske, C. H. and Subbarow, Y. (1925) The colorimetric determination of phosphorus. J. Biol. Chem. 66: 375-400.

Gornall, A.G., Bardawill, C.J. and David, M.M. (1948) Determination of serum proteins by means of the biuret reaction. J. Biol. Chem. 177: 751-766.

Goll, D. E., Robson, R. M. and Stromer, M.H. (1977) Food proteins. In: J. R. Whitaker and S. R. Tannenbaum (Eds.).pp 121.,Westport, CT: AVI Publishing Co., Inc..

King, D. R. and Poulter, R. G. (1985) Frozen storage of Indian mackerel (Rastrelliger kanagurta) and big eye (Periacanthus hamrur). Tropical Science, 25: 79-90

Kinsella, J.E. and Melachouris, N. (1976) Functional properties of proteins in foods, a survey. Crit. Rev. Food Sci. Nutr., 7: 219-280.

Kocher, P. N. and Foegeding, E. A. (1993) Micro centrifuge based method for measuring water holding of protein gels. J. Food Sci., 58: 1040-1046.

Lan, Y. H., Novakofski, J., McCuskar, R. H., Brewer, M. S., Carr, T. R. and Mc Keith, F. K. (1995) Thermal gelation of pork, beef, fish, chicken and turkey muscles as affected by heating rate and pH. J. Food Sci., 60(5): 936-940.

MacDonald, G. A. and Lanier, T. C. (1994) Actomyosin stabilization to freeze-thaw and heat denaturation by lactate salts. $J$. Food Sci., 59: 101-105.

Mehta, N.K., Elavarasan, K., Reddy, A.M. and Shamasundar, B. A. (2011) Effect of ice storage on the functional properties of proteins from a few species of fresh water fish (Indian major carps) with special emphasis on gel forming ability. J. Food Sci. Technol.,
51(4): 655-663.

Mohan, M., Ramachandran, D. and Sankar, T. V. (2006). Functional properties of Rohu (Labeo rohita) proteins during iced storage. Food Res. Intl., 39: 847854.

Parthiban, F., Sankar, T. V. and Anandan, P. (2015) Changes in soluble protein and actomyosin during chilled and frozen storage of tilapia (Oreochromis mossambicus). Fish.Technol., 52: 101108.

Parthiban, F., Sankar, T. V. and Anandan, P. (2005) Changes in the functional properties of tilapia (Oreochromis mossambicus) protein during storage in ice. Fish. Technol., 42 (2): 155-162.

Pearce, K. N. and Kinsella, J. E. (1978). Emulsifying properties of protein evaluation by a turbidimetric technique. J. Agric. Food Chem., 26: 716-723.

Ramachandran, D., Mohan, M. and Sankar, T.V. (2007) Physicochemical characteristics of muscle proteins from barracuda (Sphyraena jello) of different weight groups. LWT Food Sci. Technol., Pp. 1418-1426.

Ramachandran, D., Mohan, M., Sankar, T.V. and Anandan, R. (2009). Physicochemical and functional properties of myofibrillar proteins of fishes from different habitats. Fish Technol., 46(2): 151-158.

Roura, S.I. and Crupkin, M. (1995) Biochemical and functional properties of myofibrils from pre and postspawned hake (Merluccius hubbsi) stored on ice. J. Food Sci. 60: 269-272.

Sedlak, J. and Lindsay, R. H. (1968) Estimation of total, protein bound and non-protein sulphydryl groups in tissues with Elman's method. Analytical Biochem., 25: 192-205.

Suzuki, T. (1981) Fish and Krill Protein: Processing Technology. Applied science publishers, London. pp 1-61. 
Sankar, T. V. and Ramachandran,A. (2005) Thermal stability of myofibrillar protein fom Indian major carps. J. Sci. Food Agric., 85: 563-568.

Sankar, T. V. (2009) Functional properties of fish proteins: A Review. Fish. Technol., 46 (2): 87-98.

Talwar, P. K. and Jhingran, A. G. (1991) Inland Fishes of Indian and Adjacent Countries., Oxford and IBH Publishing Co. New Delhi, Vol. 1 \& 2. p 1097.

Watabe, S. and Ikeda, D. (2006) Diversity of the puffer fish (Takifugurubripes) fast skeletal myosin heavy chain genes. Comparative Biochem. Physiol., 1(1): 28-34.

Wild, P. J. and Clark, D. C. (1996) Foam formation and stability. pp 110-148. In G. M. Hall (Ed). Methods for testing protein functionality.

Zayas, J. F. (1997) Solubility of proteins. In: Functionality of Proteins in Food. pp 675. Springer-Verlag, Berlin, Heidelberg.

\section{How to cite this article:}

Rohini Mugale, S.B. Patange, V.R. Joshi, G.N. Kulkarni and Shirdhankar, M.M. 2018. Physico-chemical and Functional Properties of Fresh Eel (Mastacembelus armatus) Muscle Proteins. Int.J.Curr.Microbiol.App.Sci. 7(03): 2225-2231.

doi: https://doi.org/10.20546/ijcmas.2018.703.262 